\title{
Sääolot ja niiden vaikutus kasvintuotantoon Etelä-Suomessa 1966-1976
}

\author{
Ulla Lallukka ja JaAkko Mukula \\ Maatalouden tutkimuskeskus, Kasvinviljelylaitos Pl 18, 01301 Vantaa 30
}

\section{Weather conditions and their influence on plant production in southern Finland in the years $1966-1976$.}

\author{
Ulia Lallukka and JaAkKo Mukula \\ Agricultural Research Centre, Department of Plant Husbandry PB 18, 01301 Vantaa 30
}

\begin{abstract}
Absract. The climatic conditions of the southern coastal area of Finland were studied by regular wheather observations made in Tikkurila at the latitude $60^{\circ} 18^{\prime} \mathrm{N}$. Statistics on the temperature, precipitation, night frosts and sunshine hours of the growing periods, as well as the length of winters and the depth of snow cover and soil frost are given in Tables 1-6 and Figures $1 \mathrm{a}, \mathrm{b}$ and $2 \mathrm{a}, \mathrm{b}$. Similarly, information on the phenological observations of winter rye, spring wheat, oats and barley as well as on the winter damage to cereals are given in Tables $7-8$. The day degree summations requested by some cultivars of spring cereals are presented in Table 7.

Excepting the years 1968, 1974 and 1976, the growing seasons were warmer than the long term $(1930-1960)$ average. Especially warm were the summers 1972 and 1973. The precipitation, however, was less than normal, except in the years 1967 and 1972. The distribution of rains in Finland is unfavourable. The early summer is normally dry while the harvesting season is humid. Due to abundant rains harvesting difficulties as well as quality injuries in cereal crops were experienced especially in the years 1972 and 1974.

The injuries by night frosts during the growing season are normally not significant in South Finland 1975, however, night frosts occurred during the early summer at the booting stage of rye resulting in crop losses. The earliest late summer frosts occurred in 1966 and 1976 at the end of August and at the beginning of September. These frosts did not damage the field crops. The most difficult overwintering season was experienced in $1965 / 66$. Due to the abundant snow the parasitic fungi caused heavy injuries to the overwintering crops.

In measuring the growth period of cereal crops day degree summation from sowing to ripening time proved more accurate than the number of growing days.
\end{abstract}

\section{Johdanto ja aineisto}

VALle $(1958,1962$ ja 1966) on tarkastellut sääolojen vaikutusta kasvintuotantoomme Etelä-Suomessa vuosina 1946-1957, 1958-1961 ja 1962 1965. 
Taulukko 1. Lämpötilan ja sademäärän poikkeamat normaalista (1930-1960) Tikkurilassa 1966 - 1976. Table 1. Deviations from the normal (1930-1960) temperature and precipitation at Tikkurila in 1966-1976

\begin{tabular}{|c|c|c|c|c|c|c|c|c|c|c|c|c|}
\hline Kuukausi & I & II & III & IV & v & VI & VII & VIII & IX & $\mathrm{x}$ & XI & XII \\
\hline Month & \multicolumn{12}{|c|}{ Lämpötila $\left({ }^{\circ} \mathrm{C}\right)-$ Temperature $\left({ }^{\circ} \mathrm{C}\right)$} \\
\hline $\begin{array}{c}\text { Normaali } \\
\text { Normal }\end{array}$ & -6.5 & -7.1 & -3.6 & 2.9 & 9.3 & 14.3 & 17.0 & 15.4 & 10.4 & 5.1 & 0.7 & -2.6 \\
\hline 1966 & -7.4 & -6.4 & +2.2 & -30 & +0.1 & +2.6 & +0.6 & -1.0 & -1.6 & 0.0 & +1.3 & -1.4 \\
\hline 1967 & -5.9 & +2.0 & +4.1 & +0.5 & +0.6 & -0.6 & -0.3 & +0.4 & +2.2 & +3.5 & +2.9 & -7.8 \\
\hline 1968 & -8.1 & +1.9 & +2.7 & +1.3 & -1.6 & +2.3 & -1.8 & +0.8 & +0.3 & -2.4 & -0.6 & +0.7 \\
\hline 1969 & -2.7 & -2.7 & -3.1 & +0.3 & -0.6 & +1.3 & -0.5 & +0.7 & -0.5 & +0.1 & -0.3 & -4.0 \\
\hline 1970 & -3.7 & -5.7 & +1.5 & -1.4 & +0.2 & +2.4 & -0.6 & 0.0 & -0.6 & -1.0 & -1.4 & 0.0 \\
\hline 1971 & +4.4 & +1.3 & -1.1 & -0.7 & +1.2 & -0.2 & -1.5 & +0.3 & -1.6 & -0.6 & -0.7 & +0.6 \\
\hline 1972 & -2.0 & +2.6 & +0.8 & -0.8 & 0.0 & +2.2 & +3.0 & +1.2 & -0.1 & -0.3 & +0.2 & +4.6 \\
\hline 1973 & +4.8 & +2.4 & +2.4 & -0.0 & +0.9 & +2.7 & +3.1 & -0.4 & -3.0 & -2.6 & -3.6 & -1.8 \\
\hline 1974 & +3.9 & +7.0 & +2.4 & -0.2 & -2.1 & +0.3 & -1.1 & -0.7 & +2.0 & +0.8 & +1.9 & +3.7 \\
\hline 1975 & +5.5 & +4.3 & +3.5 & +0.5 & +2.4 & -0.7 & +0.8 & +0.9 & +2.6 & -0.1 & +0.7 & +0.9 \\
\hline 1976 & -3.4 & +0.1 & -1.3 & -0.9 & +1.5 & -1.3 & -1.4 & -0.6 & -2.7 & -3.5 & +0.1 & -1.5 \\
\hline
\end{tabular}

\begin{tabular}{crrrrrrrrrrrrr} 
Sodemärä $(\mathrm{mm})-$ Precipitation $(\mathrm{mm})$ \\
$\begin{array}{c}\text { Normaali } \\
\text { Normal }\end{array}$ & 50 & 34 & 30 & 43 & 40 & 48 & 73 & 75 & 69 & 70 & 66 & 58 \\
1966 & -26 & -1 & +20 & +16 & -26 & -25 & -14 & -21 & +3 & -11 & +10 & +64 \\
1967 & -16 & +13 & +26 & -10 & +13 & -29 & -34 & +32 & +6 & +72 & -9 & +3 \\
1968 & -15 & -2 & +4 & +4 & +45 & -11 & -26 & -23 & -22 & +21 & -27 & -33 \\
1969 & -6 & +8 & -22 & 0 & +1 & -30 & -10 & -47 & +26 & -18 & +61 & -35 \\
1970 & -3 & -8 & +44 & +38 & -15 & -35 & +47 & -44 & +9 & +44 & +11 & +28 \\
1971 & +5 & +31 & +18 & -28 & -31 & -27 & -48 & +15 & -7 & -13 & -26 & -6 \\
1972 & -36 & -3 & -12 & +19 & -3 & -4 & +14 & +99 & -25 & -35 & 0 & -18 \\
1973 & -32 & 0 & +7 & +25 & 0 & -24 & -58 & -43 & +48 & +5 & -25 & -8 \\
1974 & +34 & +27 & -2 & -27 & -1 & 0 & -10 & -6 & +22 & +126 & +32 & +92 \\
1975 & +7 & -18 & +3 & +20 & +6 & -37 & -28 & -27 & -32 & -43 & -25 & -7 \\
1976 & -12 & -15 & +19 & -18 & -13 & -9 & -9 & -27 & -11 & -27 & -13 & +12 \\
\hline
\end{tabular}

Tässä yhteenvedossa esitetään Tikkurilan sääolot vuosina 1966-1976. Lämpö- ja sadeoloja kuvaavat kuukausiarvot esitetään poikkeamina pitkäaikaisista (vuosien 1930-1960) keskiarvoista taulukossa 1. Taulukossa 2 tarkastellaan kasvukausien säitä yksityiskohtaisemmin, pentadeittain. Kuvissa 1 a ja 1 b havainnollistetaan niitä piirroksin. Taulukosta 3 ilmenevät vielä koko kasvukauden (touko-syyskuu) sekä touko-elokuun välisen ajan ${ }^{1}$ ) keskilämpötila, sademäärä ja tehoisa lämpötilasumma poikkeamina pitkäaikaisista keskiarvoista. Auringonpaistetuntien määrä ja haihtuminen kasvukauden eri kuukausina on esitetty taulukossa 4. Hallojen esiintyminen selviää taulukosta 5. Keskilämpötilojen ohella kuvastavat talvikausien sääoloja tiedot lumipeitepäivistä ja lumipeitteen sekä roudan vahvuudesta (taulukko 6 ja kuvat 1 a ja 2 b).

Sääolojen vaikutusta kasvillisuuden kehitykseen tarkastellaan kasvustosta tehtyjen fenologisten havaintojen avulla (taulukko 7). Talvikausien vaikutusta valaisevat tiedot syysviljojen talvituhoista (taulukko 8).

$\left.{ }^{1}\right)$ Lähes kaikkina tarkastelun kohteena olevina vuosina viljat tuleentuivat ennen syyskuun alkua. 


\section{Kasvu- ja talvikaudet Tikkurilassa vuosina $1966-1976$}

T a lvika ut en a 1965 /66 lumipeite oli paksu ja säilyi maassa pitkään. Maa routaantui ennen lumen tuloa, roudan vahvuus oli keskimäärin $30 \mathrm{~cm}$. Kovia pakkasia esiintyi tammi- ja helmikuulla. Etenkin syysvehnäja apilakasvustot talvehtivat huonosti runsaina esiintyneiden talvituhosienien vuoksi. Lumi hävisi pelloilta vasta toukokuun alkupäivinä.

$\mathrm{K}$ asvukausi 1966 . Kylvötyöt aloitettiin Tikkurilassa toukokuun toisella viikolla eli keskimäärin normaalina ajankohtana. Yleisesti ei kylvötöihin kuitenkaan päästy näin aikaisin. Kasvukausi oli erittäin vähäsateinen ja kun touko-, kesä- ja heinäkuu olivat normaalia lämpimämmät, viljojen kasvukausi jäi lyhyeksi, ja satoa saatiin vain keskinkertaisesti. Se oli kuitenkin laadultaan hyvä kuivan sään jatkuttua vielä korjuukautenakin. Heinien ja laitumien kasvu jäi erittäin heikoksi kasvukauden kuivuuden vuoksi. Syyskuussa sää muuttui sateisemmaksi ja vettä saatiin normaalimäärä, mikä loi edellytykset syyskylvöjen onnistumiselle.

T a lven $1966 / 67$ sää oli monessa suhteessa lähellä normaalia. Routaa oli kuitenkin normaalia vähemmän, joulu-maaliskuussa vain $12-19 \mathrm{~cm}$. Kasvit talvehtivat yleensä hyvin, tosin jonkin verran havaittiin talvituhosienivaurioita. Lumi ja routa hävisivät pelloilta jo huhtikuun alkupäivinä.

K a svukausi 1967 . Kevätkylvöt päästiin aloittamaan normaalia aikaisemmin, mutta kylvöaika venyi paikoin pitkäksi sateiden vuoksi. Toukokuun sää, joka oli normaalia hiukan lämpimämpi ja sateisempi, oli viljakasvien orastumiselle suotuisa. Koko kesän lämpöolot olivat kasvien kasvulle edulliset, sen sijaan sademäärä jakautui sadon muodostumisen kannalta epäsuotuisasti. Kesäkuu oli näet kuiva, mutta korjuuaikana ja syysviljojen kylvöaikana satoi runsaasti. Syysviljojen sato oli suuri, mutta korjuuajan epävakaiset säät aiheuttivat yleisesti tähkäidäntävaurioita. Kevätviljojen satotaso jäi kevätkuivuuden vuoksi vaatimattomaksi. Alkukesän lievät hallat vioittivat lähinnä perunakasvustoja ja alensivat yhdessä kevätkuivuuden kanssa perunasatoja.

T a lvikauden 1967 /68 syksy oli normaalia lämpöisempi ja sateisempi. Joulu- ja tammikuu olivat normaalia kylmemmät, mutta muut talvikuukaudet olivat lähellä pitkäaikaisia keskiarvoja. Pysyvä lumipeite saatiin joulukuussa, lumen vahvuus joulu - maaliskuulla oli $16-36 \mathrm{~cm}$. Routaa oli maaliskuulla yli $60 \mathrm{~cm}$, ja se hävisi vasta huhtikuun viimeisenä päivänä. Talvehtivat kasvit kärsivät pakkasesta ja rousteesta.

K a svukausi 1968 alkoi runsassateisena. Kylvöt aloitettiin Tikkurilassa aikaisin, mutta toukokuun 10 päivän jälkeen sateet hidastivat kylvöjen loppuun saattamista. Myöhemmin kasvukausi muuttui normaalia kuivemmaksi ja kasvustot ehtivät jo kärsiä jonkin verran kuivuudesta. Kesäkuun lopulla ja heinäkuun alussa sattuneet sateet ajoittuivat kuitenkin edullisesti kasvien kasvun kannalta. Toukokuun lopulla oli useita yöpakkasia, jotka hidastivat kasvien kehitystä. Myös heinäkuu oli normaalia lähes $2^{\circ} \mathrm{C}$ kylmempi. Auringonpaistetuntien määräkin oli normaalia pienempi. Seurauksena oli viljojen kasvuajan piteneminen. Syysviljojen puintiaikana satoi runsaasti. Kevätviljojən, heinän ja perunan sato oli kuitenkin laatunsa ja kuntonsa puolesta hyvä. 
Taulukko 2. Kasvukauden lämpötila $\left({ }^{\circ} \mathrm{C}\right)$ ja sademäärä $(\mathrm{mm})$ WMO-pentadeittain Tikkurilassa $1966-1976$. Table 2. Temperature and precipitation of WMO-five-day periods during the growing seasons $1966-1976$.

${ }^{\circ} \mathrm{C}{ }^{1966} \mathrm{~mm} \quad{ }^{\circ} \mathrm{C}{ }_{\mathrm{mm}}^{1967} \quad{ }^{\circ} \mathrm{C}{ }^{1968} \mathrm{~mm} \quad{ }^{\circ} \mathrm{C}{ }^{1969} \mathrm{~mm} \quad{ }^{\circ} \mathrm{C}{ }_{\mathrm{mm}}^{1970}$

Toukokuu - May

\begin{tabular}{|c|c|c|c|c|c|c|c|c|c|c|}
\hline $1-5$ & 6.9 & - & 4.5 & 11.2 & 7.4 & 4.9 & 3.8 & - & 7.4 & 4.0 \\
\hline $6-10$ & 4.6 & 0.9 & 7.2 & 0.5 & 7.7 & 9.0 & 10.1 & 6.0 & 10.5 & - \\
\hline $11-15$ & 10.8 & - & 11.1 & 1.4 & 8.7 & 48.6 & 8.8 & 15.6 & 10.6 & - \\
\hline $16-20$ & 14.1 & 2.0 & 8.7 & 21.1 & 5.6 & 20.0 & 8.1 & 18.6 & 7.9 & 2.9 \\
\hline $21-25$ & 10.4 & 9.6 & 12.3 & 16.7 & 4.1 & 2.9 & 8.5 & 0.7 & 8.2 & 12.0 \\
\hline \multirow[t]{2}{*}{$26-30$} & 9.7 & 1.7 & 14.2 & 1.7 & 11.2 & - & 12.3 & - & 12.3 & 1.1 \\
\hline & 9.4 & 14.2 & 9.7 & 52.6 & 7.5 & 85.4 & 8.6 & 30.9 & 9.5 & 20.0 \\
\hline
\end{tabular}

Kesäkuu - June

$$
\begin{array}{r}
31 / 5-4 \\
5-9 \\
10-14 \\
15-19 \\
20-24 \\
25-29
\end{array}
$$

\begin{tabular}{rrrrrrrrrr}
9.9 & 13.3 & 14.8 & 1.1 & 14.5 & - & 11.2 & 0.0 & 12.6 & 5.3 \\
14.1 & 4.4 & 11.1 & 9.7 & 14.8 & 3.7 & 11.2 & 9.2 & 18.3 & - \\
18.8 & - & 9.9 & 1.9 & 16.8 & - & 16.9 & - & 15.7 & 1.8 \\
18.7 & - & 16.9 & - & 18.7 & 0.3 & 18.7 & - & 15.9 & 7.1 \\
20.4 & - & 15.5 & 4.8 & 20.0 & 3.2 & 16.6 & 7.4 & 17.6 & - \\
17.7 & 5.6 & 14.7 & 1.3 & 14.8 & 29.8 & 18.5 & 1.0 & 18.2 & 3.8 \\
\hline 16.6 & 23.3 & 13.8 & 18.8 & 16.6 & 37.0 & 15.5 & 17.6 & 16.4 & 18.0 \\
\hline
\end{tabular}

Heinäkuu - July

$$
\begin{array}{r}
30 / 6-4 \\
5-9 \\
10-14 \\
15-19 \\
20-24 \\
25-29
\end{array}
$$

\begin{tabular}{rrrrrrrrrr}
16.0 & 4.0 & 15.4 & 14.8 & 18.6 & - & 14.2 & 26.5 & 17.7 & 5.3 \\
15.9 & 2.1 & 16.4 & 0.2 & 15.7 & 36.6 & 15.8 & 14.0 & 16.5 & 13.3 \\
26.5 & 26.3 & 15.8 & 1.9 & 13.4 & 30.5 & 16.2 & 14.7 & 16.0 & 38.9 \\
16.5 & 4.2 & 16.1 & 0.5 & 13.5 & 1.9 & 15.8 & 6.0 & 15.8 & 25.0 \\
22.0 & 7.8 & 17.1 & 12.4 & 12.6 & 2.3 & 17.2 & - & 15.4 & 29.8 \\
18.8 & 13.1 & 17.5 & 9.8 & 16.0 & 2.2 & 18.0 & 2.2 & 17.3 & 5.9 \\
\hline 17.6 & 57.5 & 16.4 & 39.6 & 15.0 & 67.5 & 16.2 & 63.4 & 16.5 & 118.2 \\
\hline
\end{tabular}

Elokuu - August

$$
\begin{array}{r}
30 / 7-3 \\
4-8 \\
9-13 \\
14-18 \\
19-23 \\
24-28
\end{array}
$$

\begin{tabular}{rrrrrrrrrr}
17.3 & 9.3 & 20.5 & 0.2 & 16.8 & 0.3 & 19.0 & - & 18.1 & 1.6 \\
16.0 & 20.0 & 16.9 & 12.7 & 16.3 & 2.6 & 17.4 & - & 15.7 & 1.5 \\
16.0 & 28.6 & 16.7 & 3.3 & 15.3 & 8.9 & 17.8 & - & 16.0 & 17.6 \\
14.2 & 2.4 & 16.7 & 11.1 & 14.6 & 22.0 & 14.7 & - & 16.3 & 6.2 \\
14.0 & 0.0 & 14.5 & 23.1 & 17.2 & 3.1 & 15.4 & 8.3 & 15.4 & 5.0 \\
11.6 & 0.0 & 14.4 & 53.7 & 17.1 & 1.3 & 14.9 & 12.5 & 12.0 & 0.3 \\
\hline 14.9 & 60.3 & 15.9 & 104.1 & 16.2 & 38.2 & 16.5 & 20.8 & 15.6 & 32.2 \\
\hline
\end{tabular}

Syyskuu - September

\begin{tabular}{crrrrrrrrrr}
$29-8-2$ & 12.4 & 3.7 & 13.4 & 26.5 & 17.4 & 14.3 & 13.7 & 13.5 & 14.7 & - \\
$3-7$ & 13.7 & 24.7 & 17.6 & 11.9 & 19.1 & 0.4 & 10.2 & 5.5 & 11.3 & 33.9 \\
$8-12$ & 9.3 & 5.4 & 14.8 & 7.6 & 12.3 & 8.3 & 14.1 & - & 10.0 & 13.0 \\
$13-17$ & 10.9 & 22.4 & 12.0 & 0.5 & 6.3 & 7.5 & 10.9 & 24.3 & 13.2 & 20.3 \\
$18-22$ & 7.5 & 4.9 & 10.7 & 17.5 & 8.2 & 18.8 & 6.1 & 28.3 & 11.0 & 8.2 \\
$23-17$ & 4.4 & 8.9 & 10.8 & 14.4 & 7.1 & 11.0 & 9.4 & 23.4 & 4.8 & 2.4 \\
\cline { 2 - 10 } & 9.7 & 70.0 & 13.2 & 78.4 & 14.1 & 60.3 & 10.7 & 96.0 & 10.8 & 77.8 \\
\hline
\end{tabular}

Lokakuu - October

\begin{tabular}{crrrrrrrrrr}
$28 / 9-2$ & 5.2 & 3.7 & 8.4 & 4.4 & 7.1 & 0.8 & 6.6 & 26.8 & 5.2 & - \\
$3-7$ & 7.9 & 14.0 & 12.2 & 23.5 & 3.7 & 8.3 & 5.4 & 0.9 & 4.5 & 0.1 \\
$8-12$ & 4.8 & 6.6 & 8.8 & 32.0 & 2.0 & 14.3 & 7.5 & 1.1 & 7.4 & 2.9 \\
$13-17$ & 5.6 & 1.7 & 9.7 & 42.0 & 5.5 & 16.9 & 8.3 & - & 6.7 & - \\
$18-22$ & 8.7 & 25.6 & 4.2 & 20.7 & 3.9 & 4.2 & 5.2 & 0.2 & 6.7 & 92.2 \\
$23-27$ & 3.1 & 6.5 & 6.8 & 10.6 & -1.7 & 6.1 & 2.4 & 15.6 & 1.4 & 3.4 \\
$28-1 / 11$ & -1.3 & 3.0 & 8.3 & 21.6 & -0.1 & 45.9 & 0.8 & 24.1 & -1.4 & 13.6 \\
\cline { 2 - 10 } & 4.9 & 62.1 & 9.3 & 154.8 & 2.9 & 96.5 & 5.2 & 68.7 & 6.1 & 112.2 \\
\hline
\end{tabular}




\begin{tabular}{|c|c|c|c|c|c|c|c|c|c|c|c|}
\hline \multicolumn{2}{|c|}{1971} & \multicolumn{2}{|c|}{1972} & \multicolumn{2}{|c|}{1973} & \multicolumn{2}{|c|}{1974} & \multicolumn{2}{|c|}{1975} & \multicolumn{2}{|c|}{1976} \\
\hline${ }^{\circ} \mathrm{C}$ & $\mathrm{mm}$ & ${ }^{\circ} \mathrm{C}$ & $\mathrm{mm}$ & ${ }^{\circ} \mathrm{C}$ & $\mathrm{mm}$ & ${ }^{\circ} \mathrm{C}$ & $\mathrm{mm}$ & ${ }^{\circ} \mathrm{C}$ & $\mathrm{mm}$ & ${ }^{\circ} \mathrm{C}$ & $\mathrm{mm}$ \\
\hline 5.0 & 3.1 & 10.8 & 0.1 & 7.7 & 4.1 & 5.3 & - & 9.8 & 0.1 & 4.5 & 7.2 \\
\hline 11.2 & - & 6.6 & 0.7 & 7.7 & 1.3 & 4.4 & 18.0 & 13.5 & 0.0 & 9.6 & 0.8 \\
\hline 11.4 & 0.3 & 6.7 & 3.7 & 9.1 & 2.7 & 7.2 & - & 13.6 & 12.3 & 14.0 & - \\
\hline 13.9 & - & 9.6 & - & 8.2 & 31.1 & 10.9 & 0.0 & 18.1 & 2.3 & 14.3 & - \\
\hline 5.6 & 1.8 & 12.0 & 18.1 & 14.3 & 0.0 & 7.1 & 4.0 & 4.0 & 9.2 & 14.0 & - \\
\hline 15.0 & 3.8 & 9.7 & 14.2 & 12.9 & 0.6 & 8.1 & 12.5 & 7.1 & 10.1 & 9.0 & 1.7 \\
\hline 10.3 & 9.0 & 9.2 & 36.8 & 10.0 & 39.8 & 7.2 & 34.5 & 12.2 & 38.1 & 10.9 & 9.7 \\
\hline
\end{tabular}

\begin{tabular}{rrrrrrrrrrrr}
17.5 & 0.0 & 10.8 & 0.5 & 17.6 & - & 10.3 & 6.4 & 7.8 & 10.4 & 9.4 & 19.9 \\
12.7 & - & 16.5 & - & 17.2 & - & 11.8 & 12.2 & 14.9 & - & 10.9 & 3.8 \\
10.9 & 6.9 & 14.9 & 0.0 & 13.7 & 7.8 & 13.4 & 19.3 & 13.7 & 0.0 & 12.5 & 2.4 \\
12.7 & 5.9 & 15.1 & 15.3 & 13.0 & - & 18.9 & - & 14.3 & 7.1 & 12.6 & 16.4 \\
16.8 & 7.1 & 16.2 & 28.0 & 18.4 & 11.8 & 17.6 & 3.1 & 17.2 & 0.1 & 15.6 & 13.5 \\
15.5 & 0.8 & 22.5 & 0.0 & 21.2 & 2.3 & 14.4 & 11.5 & 12.7 & 1.2 & 17.5 & - \\
\hline 14.3 & 20.7 & 16.0 & 43.8 & 16.9 & 21.9 & 14.4 & 52.5 & 13.4 & 18.8 & 13.1 & 56.0 \\
\hline
\end{tabular}

\begin{tabular}{rrrrrrrrrrrr}
17.8 & 5.1 & 23.0 & 2.3 & 21.0 & 2.2 & 15.4 & 0.0 & 16.7 & - & 16.4 & 6.0 \\
18.9 & - & 19.6 & 39.0 & 22.4 & - & 16.3 & 7.7 & 17.1 & - & 12.1 & 19.6 \\
16.8 & 2.1 & 21.4 & 8.3 & 19.4 & - & 15.7 & 28.1 & 17.8 & 4.5 & 15.5 & 1.1 \\
13.1 & 12.6 & 20.1 & 6.4 & 21.6 & 1.5 & 17.3 & 3.5 & 15.6 & 28.4 & 17.3 & 3.6 \\
15.9 & 0.1 & 18.6 & 0.1 & 17.5 & 9.9 & 16.8 & 2.2 & 18.5 & 3.8 & 18.6 & 7.6 \\
19.1 & 0.8 & 18.4 & 30.6 & 19.0 & 3.7 & 14.8 & 20.8 & 19.9 & 7.9 & 16.4 & 8.6 \\
\hline 16.9 & 20.7 & 20.2 & 86.7 & 20.2 & 17.3 & 16.1 & 62.3 & 17.6 & 44.6 & 16.1 & 46.5 \\
\hline
\end{tabular}

\begin{tabular}{rrrrrrrrrrrr}
18.6 & 23.9 & 20.1 & 4.3 & 18.1 & 2.1 & 14.4 & 3.5 & 19.9 & - & 13.8 & 57.2 \\
18.4 & 8.8 & 18.2 & 35.2 & 18.3 & 19.5 & 13.5 & 22.0 & 22.2 & - & 14.9 & 1.9 \\
16.1 & 4.7 & 17.6 & 70.4 & 15.5 & 1.0 & 14.6 & 28.4 & 15.8 & 1.1 & 16.2 & 0.3 \\
14.9 & 16.0 & 15.8 & 13.1 & 19.5 & 0.1 & 15.4 & 2.3 & 13.4 & 15.7 & 17.1 & 1.0 \\
13.4 & 0.0 & 19.2 & 15.3 & 12.3 & 6.9 & 13.3 & 9.2 & 16.7 & 2.9 & 13.0 & 1.4 \\
14.5 & 22.1 & 13.0 & 35.3 & 9.5 & 1.9 & 15.3 & 0.7 & 13.9 & 4.2 & 14.2 & - \\
\hline 16.0 & 75.5 & 17.3 & 173.6 & 15.5 & 31.5 & 14.4 & 66.1 & 17.0 & 23.7 & 14.9 & 61.8 \\
\hline
\end{tabular}

\begin{tabular}{rrrrrrrrrrrr}
12.4 & 42.5 & 10.3 & 0.7 & 12.3 & 39.8 & 15.2 & 4.0 & 13.6 & 23.6 & 15.3 & 9.4 \\
11.0 & 0.3 & 10.8 & 6.7 & 10.9 & 9.4 & 16.7 & 23.6 & 12.9 & 26.8 & 9.6 & 15.3 \\
9.8 & 10.6 & 14.9 & 24.2 & 7.8 & 26.8 & 12.5 & 18.2 & 13.6 & 0.3 & 9.8 & 36.1 \\
4.7 & 1.0 & 12.6 & 4.0 & 5.3 & 1.2 & 9.4 & 0.0 & 14.2 & 4.5 & 11.3 & 0.7 \\
8.8 & 2.0 & 9.6 & 2.4 & 6.7 & 4.9 & 11.1 & 12.7 & 12.0 & 2.1 & 5.6 & 0.5 \\
9.7 & 25.1 & 7.0 & 2.9 & 3.8 & 8.7 & 12.2 & 34.7 & 13.2 & 15.4 & 4.8 & 0.6 \\
\hline 9.4 & 81.5 & 10.9 & 40.9 & 7.8 & 90.8 & 12.9 & 93.2 & 13.3 & 72.7 & 9.4 & 62.6 \\
\hline
\end{tabular}

\begin{tabular}{rrrrrrrrrrrr}
7.6 & 3.1 & 4.2 & 3.5 & 8.1 & 37.8 & 11.9 & 26.0 & 10.5 & 7.8 & 0.9 & 0.7 \\
5.3 & 14.9 & 8.1 & 1.4 & 8.3 & 0.6 & 9.0 & 67.5 & 8.4 & 7.3 & 3.1 \\
6.5 & 3.8 & 8.9 & 5.9 & 3.1 & 35.0 & 7.1 & 25.2 & 2.6 & 0.7 & 4.7 & 14.4 \\
1.4 & 2.9 & 6.0 & 0.6 & 0.5 & 19.8 & 3.6 & 2.6 & 7.2 & 3.6 & -0.1 & 0.7 \\
6.1 & 22.3 & 2.2 & 8.3 & -2.3 & 0.8 & 4.9 & 12.2 & 0.4 & 0.1 & -0.4 & - \\
1.4 & 5.7 & 2.6 & 12.3 & 1.8 & 6.1 & 3.2 & 25.7 & 6.6 & 3.8 & 1.7 & 3.5 \\
4.4 & 5.6 & 1.3 & 24.5 & 0.5 & 2.5 & 4.9 & 43.1 & 1.1 & 14.7 & -0.9 & 27.2 \\
\hline 4.7 & 58.3 & 4.8 & 56.5 & 2.9 & 102.6 & 7.4 & 202.3 & 6.1 & 38.0 & 1.1 & 53.0 \\
\hline
\end{tabular}




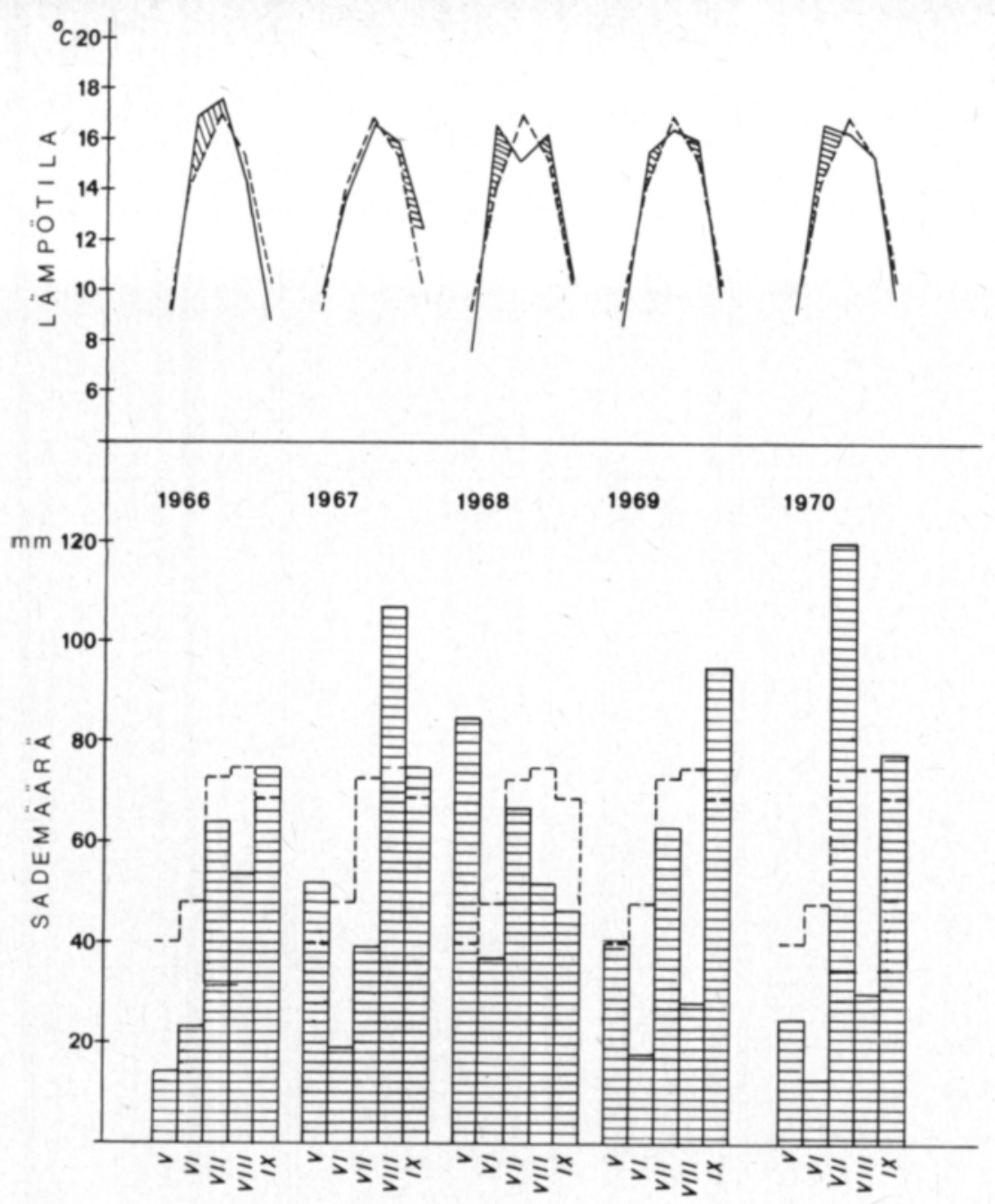

Kuva 1. a. Kasvukausien 1966-1970 sademäärät ja keskilämpötilat kuukausittain Tikkurilassa normaaliarvoihin (katkoviiva) verrattuna.

Fig. 1 a. Monthly precipitation and mean temperature in the growing seasons 1966-1970 compared with the normal values (dash line).

T a lvi $1968 / 69$ oli normaalia kylmempi ja runsasluminen. Maa routaantui jo marraskuussa, ja routa hävisi vasta huhtikuun lopulla.

K a svuka usi 1969 . Kevätkylvöt aloitettiin normaaliin aikaan. Kylvöaikana sattunut viikon sadekausi viivästytti kylvötöitä. Kasvukausi oli lämpöoloiltaan normaali, mutta sademäärä Tikkurilassa oli vain $\mathbf{8 0 \%}$ normaalista. Viljojen satotaso oli kohtalainen ja edullisen korjuukauden vuoksi myös kunnoltaan hyvä. Sekä kevät- että syyshallat olivat niin lieviä, etteivät ne aiheuttaneet satovahinkoja perunallekaan.

Talvi $1969 / 70$ oli normaalia huomattavasti kylmempi. Pysyvä lumipeite saatiin marraskuun lopulla ja lumikausi päättyi vasta 24/4. Lumipeite oli paksu, routakerros sen sijaan normaali. Routa suli kokonaan vasta toukokuun alkupäivinä. 


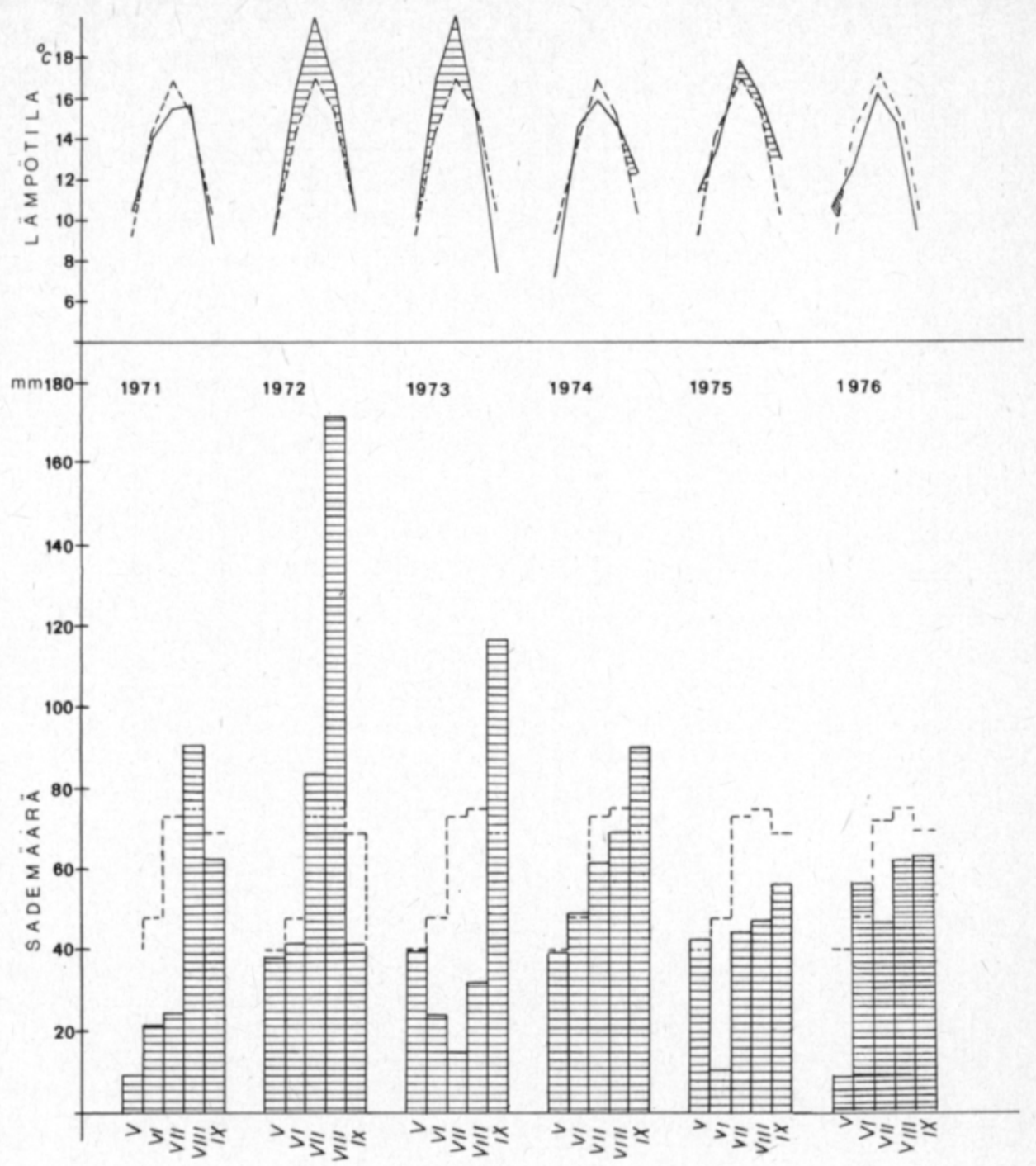

Kuva 1 b. Kasvukausien $1971-1976$ sademäärät - - -

Fig. 1 b. Monthly precipitation - - 1971-1976 compared - -

K a s v u k a us 1970 . Kesäkuukaudet olivat heinäkuuta lukuunottamatta normaalia lämpimämmät. Keväthalloja esiintyi toukokuussa, mutta ei enää perunan taimistumisen jälkeen, eivätkä ne liioin aiheuttaneet vahinkoja muille kasveille. Kylvöt saatiin tehtyä toukokuun alussa, joka oli sateeton. Toukokuun lopulla satoi, mutta sademäärät jäivät vähäisiksi. Kesäkuu oli niinikään kuiva. Heinäkuun runsaat sateet sen sijaan vaikeuttivat heinänkorjuuta ja heikensivät heinäsadon laatua. Myöhään tullut sade aiheutti viljakasvustoihin runsaasti jälkiversontaa. Elokuu oli kuiva ja viljat tuleentuivat varhain, joten ne saatiin korjattua suotuisten sääolojen vallitessa. Syyskuun jatkuvat sateet ajoittuivat päasiassa 10. päivän jälkeen, jota ennen syyskylvöt ehdittiin tehdä. 
Taulukko 3. Kasvukauden (touko-syyskuun ja touko-elokuun) keskilämpötilan ja sademäärän sekä $5^{\circ} \mathrm{C}$ ylittävien lämpötilojen summan poikkeamat normaaliarvoista Tikkurilassa 1966-1976.

Table 3. Deviations from the normal temperature, precipitation and day-degree summation above $5^{\circ} \mathrm{C}$ in the growing seasons (May-September and May-August) 1966-1976 at Tikkurila.

\begin{tabular}{|c|c|c|c|c|c|c|c|c|c|c|c|}
\hline $\begin{array}{c}\text { Normaali } \\
\text { Normal }\end{array}$ & 1966 & 1967 & 1968 & 1969 & 1970 & 1971 & 1972 & 1973 & 1974 & 1975 & 1976 \\
\hline
\end{tabular}

Lämpötilan poikkeama normaalista - Deviation of temperature from normal $\left({ }^{\circ} \mathrm{C}\right)$

$\begin{array}{llllccccccccc}\text { V-IX } & 13.2 & +0.2 & +0.7 & 0 & +0.2 & +0.4 & 0 & +1.3 & +0.7 & -0.3 & +1.3 & -0.8 \\ \text { V-VIII } & 14.0 & +0.6 & +0.1 & -0.1 & +0.2 & +0.5 & +0.2 & +1.6 & +1.6 & -0.9 & +0.9 & -0.4\end{array}$

Sademäărăn poikkeama normaalista - Deviation of total precipitation from normal ( $\mathrm{mm}$ )

\begin{tabular}{|c|c|c|c|c|c|c|c|c|c|c|c|c|}
\hline$V-I X$ & 236 & -81 & -18 & +6 & -86 & -48 & -91 & +105 & -125 & -17 & -87 & +1 \\
\hline V-VIII & 305 & -77 & -12 & -17 & -60 & -39 & -97 & +80 & -77 & +5 & -99 & -48 \\
\hline
\end{tabular}

Tehoisan $\left(5^{\circ} \mathrm{C}\right)$ ylittävien) lämpötilasumman poikkeama normaalista Deviation of day degree summation (above $5^{\circ} \mathrm{C}$ ) from normal

\begin{tabular}{lllllllllllll} 
V-IX & 1254 & +53 & +96 & +27 & +37 & +57 & +44 & +211 & +124 & -4 & +202 & -91 \\
V-VIII & 1107 & +74 & +16 & -4 & +37 & +61 & +18 & +198 & +192 & -80 & +110 & -47 \\
\hline
\end{tabular}

Taulukko 4. Auringonpaistetunnit ja haihtuminen vesialtaasta Tikkurilassa 1966-1976.

Table 4. Sunshine hours and evaporation from open tank at Tikkurila in 1966-1976.

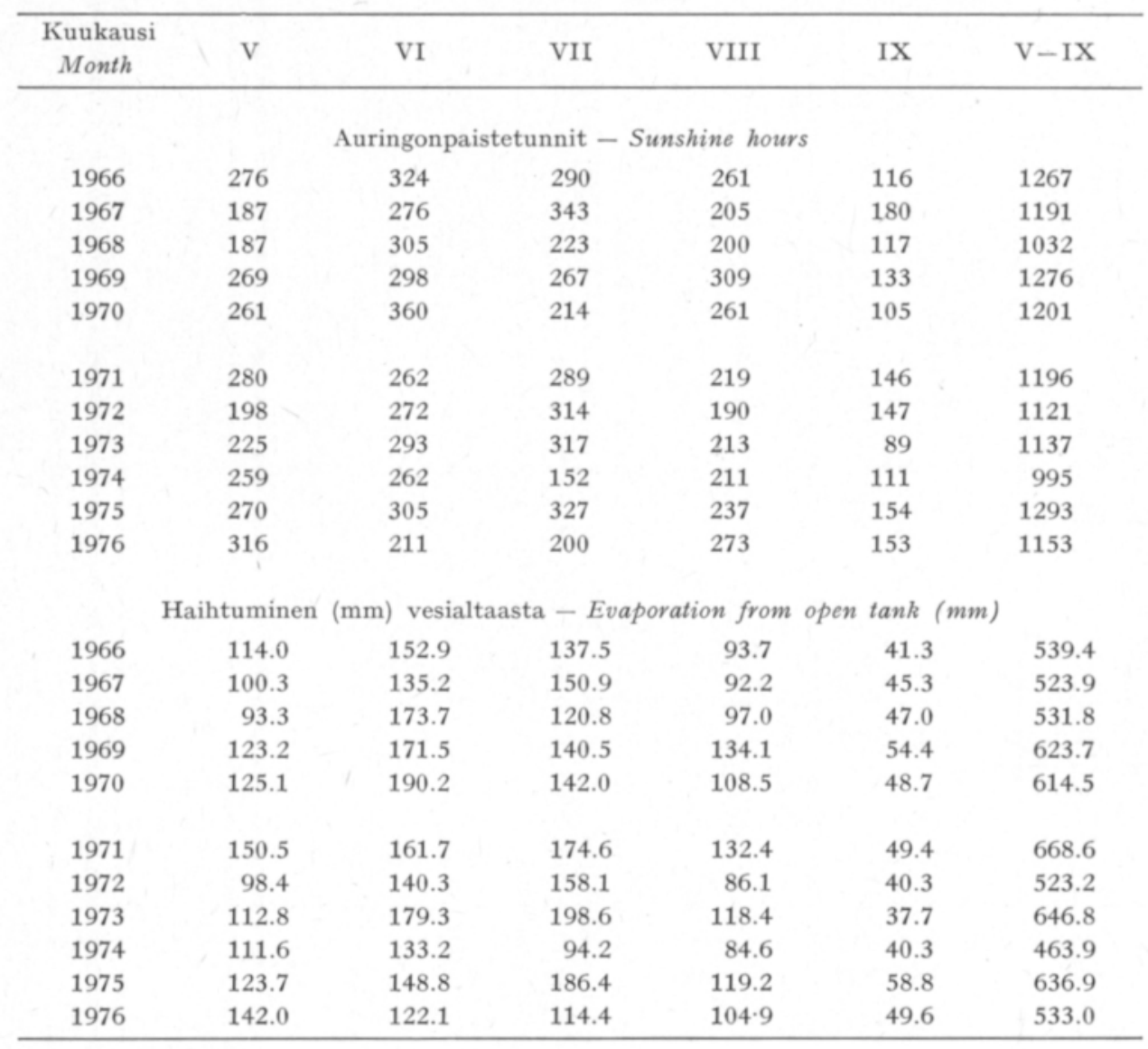


Taulukko 5. Hallat Tikkurilassa $1966-1976\left({ }^{\circ} \mathrm{C}\right.$ ma an pinnalla). (Keväăn ja syksyn rajakohdaksi on otettu 1/7).

Table 5. Frost data of growinv seasons in 1966-1976 at Tikkurila $\left({ }^{\circ} \mathrm{C}\right.$ on the ground). (The first of July is set as the border line between spring and summer.)

\begin{tabular}{|c|c|c|c|c|c|c|c|c|c|c|}
\hline & \multicolumn{5}{|c|}{$\begin{array}{l}\text { Lievä halla }\left(0--2.1^{\circ} \mathrm{C}\right) \\
\text { Light frost }\left(0--2.1^{\circ} \mathrm{C}\right)\end{array}$} & \multicolumn{5}{|c|}{$\begin{array}{c}\text { Ankara halla }\left(-2.2^{\circ} \mathrm{C} \text { tai kylmempi) }\right. \\
\text { Killing frost }\left(-2.2^{\circ} \mathrm{C} \text { or bellow }\right)\end{array}$} \\
\hline & $\begin{array}{r}\text { Viir } \\
\text { kev } \\
L a \\
s p\end{array}$ & $\begin{array}{l}\text { einen ( } \\
\text { äällä } \\
\text { st in } \\
\text { ring }\end{array}$ & $\begin{array}{r}\text { Ensir } \\
\text { sy } \\
F i \\
\text { au }\end{array}$ & $\begin{array}{l}\text { mãinen } \\
\text { syllä } \\
\text { st in } \\
\text { umn }\end{array}$ & $\begin{array}{c}\text { Hallattomia } \\
\text { päiviä } \\
\text { Frostfree } \\
\text { days }\end{array}$ & $\begin{array}{r}\text { Vii } \\
\text { ke } \\
L \\
s p\end{array}$ & $\begin{array}{l}\text { neinen } \\
\text { äällä } \\
\text { st in } \\
\text { ing }\end{array}$ & $\begin{array}{r}\text { Ensim } \\
\text { syk } \\
\text { Firs } \\
\text { aut }\end{array}$ & $\begin{array}{l}\text { mäinen } \\
\text { syllä } \\
t \text { in } \\
u m n\end{array}$ & $\begin{array}{c}\text { Hallattomia } \\
\text { päiviä } \\
\text { Frostfree } \\
\text { days }\end{array}$ \\
\hline 1966 & $1 / 6$ & $(-3.0)$ & $26 / 8$ & $(-1.3)$ & 86 & $1 / 6$ & $(-3.0)$ & $29 / 8$ & $(-3.0)$ & 89 \\
\hline 1967 & $10 / 6$ & $(-1.0)$ & $3 / 7$ & $(-1.5)$ & 23 & $2 / 5$ & $(-4.0)$ & $28 / 9$ & $(-2.9)$ & 149 \\
\hline 1968 & $4 / 6$ & $(-0.2)$ & $13 / 9$ & $(-2.5)$ & 101 & $28 / 5$ & $(-2.3)$ & $13 / 9$ & $(-2.5)$ & 108 \\
\hline 1969 & $7 / 6$ & $(-1.5)$ & $6 / 9$ & $(-2.2)$ & 91 & $25 / 5$ & $(-5.1)$ & $6 / 9$ & $(-2.2)$ & 104 \\
\hline 1970 & $25 / 5$ & $(-3.0)$ & $27 / 8$ & $(-2.5)$ & 94 & $25 / 5$ & $(-3.0)$ & $27 / 8$ & $(-2.5)$ & 94 \\
\hline 1971 & $16 / 6$ & $(-0.3)$ & $22 / 8$ & $-0.5)$ & 67 & $15 / 5$ & $(-5.4)$ & $14 / 9$ & $(-4.9)$ & 122 \\
\hline 1972 & $4 / 6$ & $(-0.1)$ & $2 / 8$ & $(-0.4)$ & 59 & $18 / 5$ & $(-2.9)$ & $20 / 8$ & $(-3.8)$ & 94 \\
\hline 1973 & $12 / 6$ & $(-0.7)$ & $23 / 8$ & $(-1.5)$ & 72 & $9 / 5$ & $(-3.1)$ & $27 / 8$ & $(-4.3)$ & 110 \\
\hline 1974 & $6 / 6$ & $(-1.4)$ & $14 / 9$ & $(-0.2)$ & 100 & $5 / 6$ & $(-2.2)$ & $16 / 10$ & $(-5.4)$ & 103 \\
\hline 1975 & $11 / 6$ & $(-0.2)$ & $31 / 8$ & $(-0.2)$ & 81 & $3 / 6$ & $(-3.6)$ & $30 / 9$ & $(-2.7)$ & 109 \\
\hline 1976 & $10 / 6$ & $(-1.3)$ & $22 / 8$ & $(-0.1)$ & 73 & $1 / 5$ & $(-7.6)$ & $5 / 9$ & $(-3.0)$ & 127 \\
\hline
\end{tabular}

T a lvi $1970 / 71$ oli leuto, ja lumipeite sekä routakerros olivat ohuet. Lunta oli eniten $(30 \mathrm{~cm})$ maaliskuussa, samoin routaa $(32 \mathrm{~cm})$. Tammikuu oli erityisen lämmin ja runsassateinen ja siten jääpoltteen muodostumiselle otollinen. Kuitenkin syysviljat kärsivät talvituhoista odotettua vähemmän, rypsi sen sijaan talvehti heikommin. Nurmissa todettiin niinikään aukkoisuutta. Apilassa havaittiin apilamädän aiheuttamaa tuhoa.

K a s v u k a usi 1971 . Kevätkylvöt aloitettiin Tikkurilassa normaaliin aikaan. Kasvukausi oli heinäkuuta lukuunottamatta lämpöoloiltaan lähellä pitkäaikaisia keskiarvoja. Sademäärät olivat niukat, ainoastaan elokuussa satoi keskimääräistä hiukan enemmän. Elonkorjuu sujui silti Tikkurilassa vaikeuksitta, samoin syysviljojen kylvö. Lieviä keväthalloja esiintyi toukokuun ja syyshalloja elokuun lopulla. Elokuun hallat vahingoittivat perunan lehdistöä, muut kasvustot eivät niistä kärsineet.

T a lven 1971 / 72 kuukausista loka-, marras-, tammi- ja huhtikuu olivat keskimääräistä kylmempiä, joulu-, helmi- ja maaliskuu sen sijaan normaalia lämpimämpiä. Talvi oli vähäluminen ja routakerros vahvistui tammikuun pakkasten seurauksena yli $60 \mathrm{~cm}$ :ksi ja suli vasta toukokuun alussa. Viljat ja nurmet talvehtivat hyvin, syysrypsi heikommin.

K a svukausi 1972 . Kylvötyöt päästiin aloittamaan normaaliin aikaan. Toukokuun lopulla tuli runsaita sateita, mutta kylvöt Etelä-Suomessa oli saatu silloin jo pääosin tehdyksi. Kasvuolot olivat kylvöjen jälkeen edulliset. Lämpötilat olivat kesä-, heinä- ja elokuun aikana erittäin korkeat. Sateet sattuivat alkukesästä kasvien kasvun ja sadon muodostuksen kannalta edulliseen aikaan. Helteisen sään johdosta kasvustot tuuleentuivat erittäin nopeasti. Kasvukauden loppupuoli ei enää ollutkaan yhtä suotuisa. Korjuukausi 
Taulukko 6. Talvikausien säät Tikkurilassa 1966-1976.

Table 6. Winter weather conditions at Tikkurilà in 1966-1976.

Talvi-

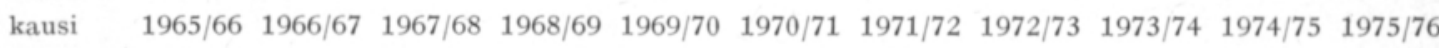

Winter

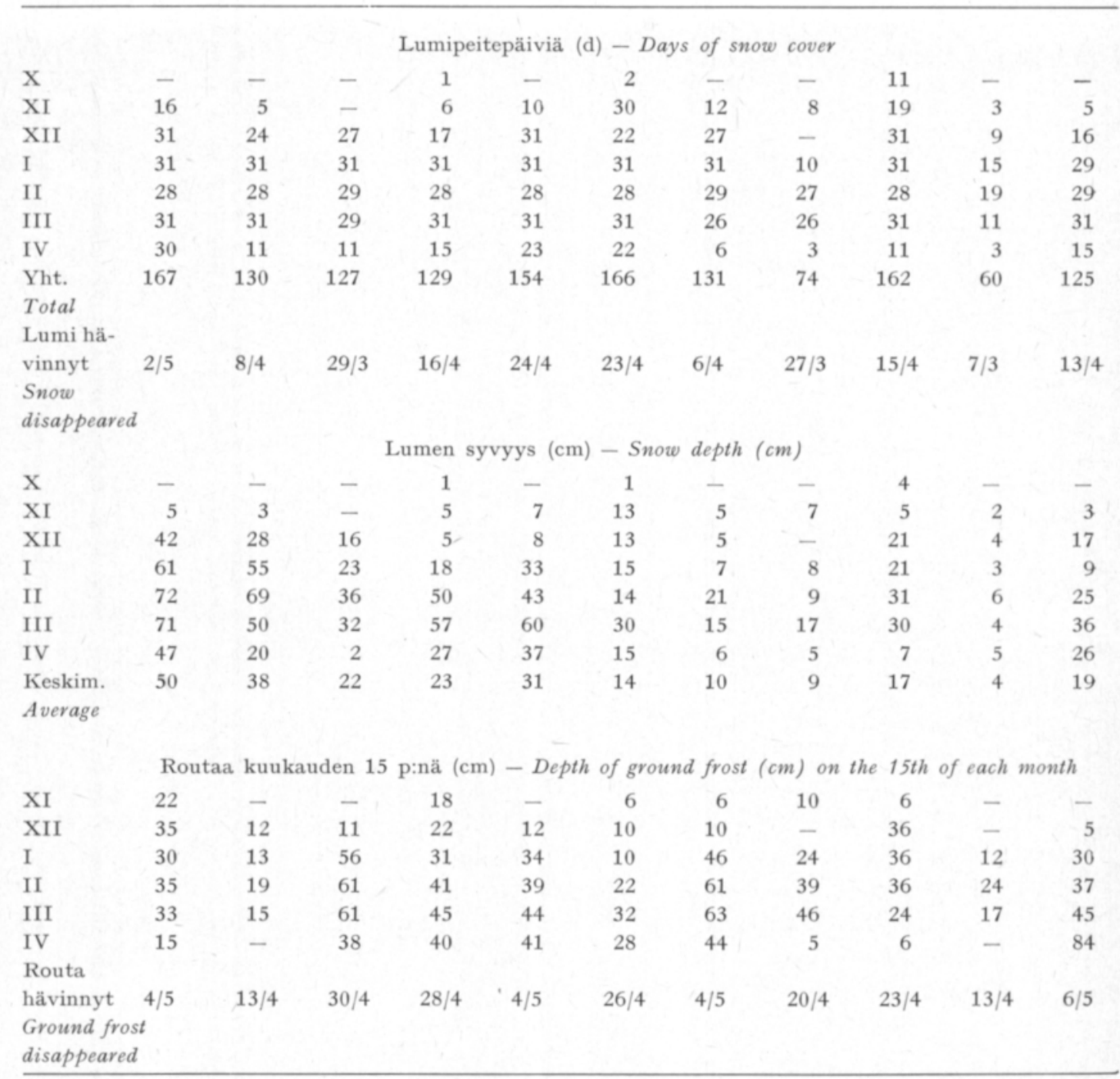

tosin alkoi hyvin, vaikka sadetta saatiin paikoin runsaastikin, mutta sadepäivien luku jäi vähäiseksi. Elokuun toisella kolmanneksella alkaneet yhtämittaiset sateet muuttivat kuitenkin lupaavasti alkaneen korjuun erittäin hankalaksi. Viljat lakoutuivat, ja tähkäidäntä sekä runsaana esiintynyt punahome heikensivät sadon laatua. Kevätviljojen sadot olivat määrältään normaaleja. Syysviljat sen sijaan lakoutuivat voimakkaan kasvun vuoksi sangen varhaisessa kehitysvaiheessa, jonka vuoksi jyvän koko jäi pieneksi ja satotaso alhaiseksi. Heinät saatiin korjatuksi hyvien säiden vallitessa, joten heinäsadon laatu oli hyvä. Perunaruttoa esiintyi runsaasti syyskesän runsaiden 


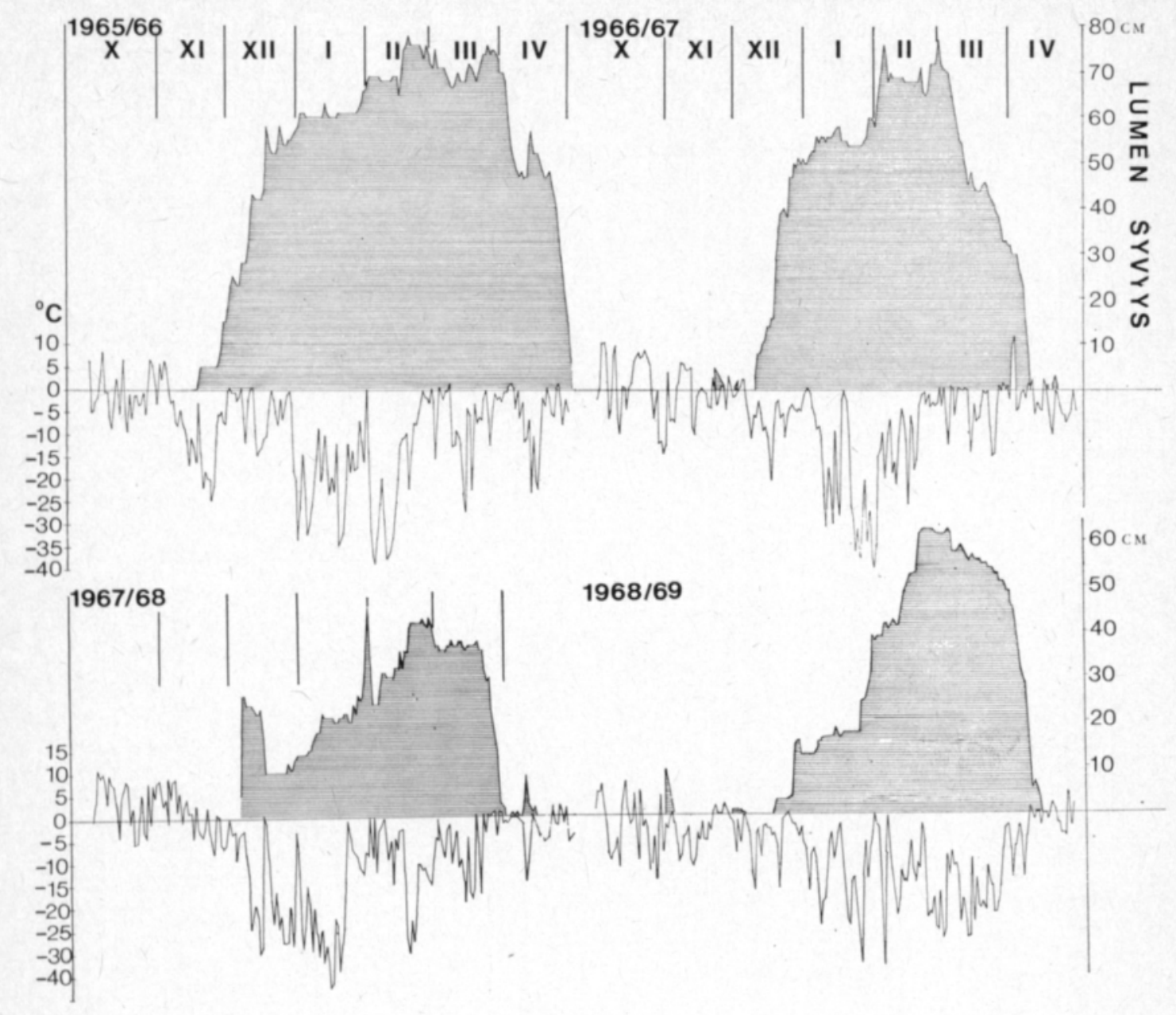

Kuva 2 a. Lumen syvyys (viivoitettu) ja alin lämpötila maan tai lumen pinnalla Tikkurilassa talvikausina 1965/66-1969/70. Fig. 2 a. Depth of snow (shaded) and minimum temperature on the ground or snow surface at Tikkurila in the winters 1965/66-1969/70.

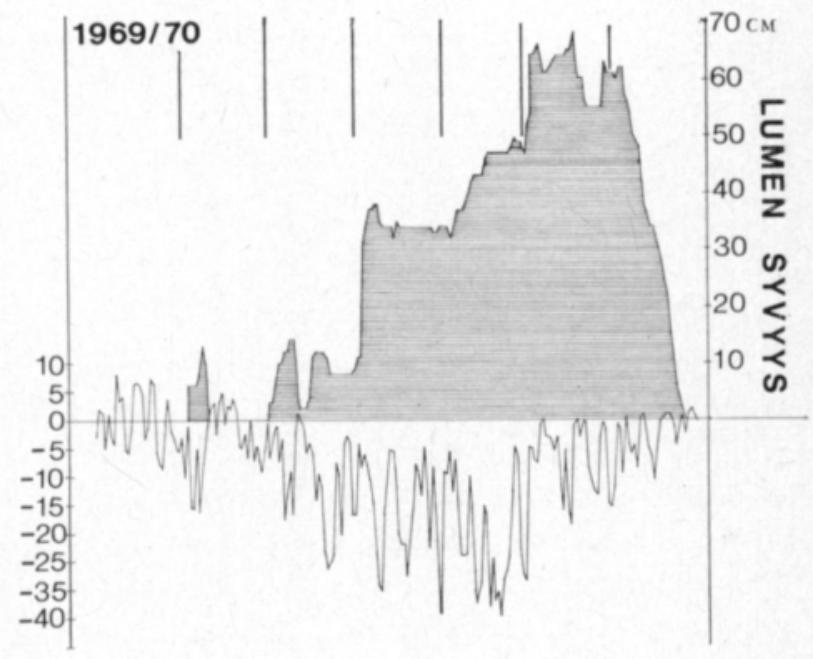



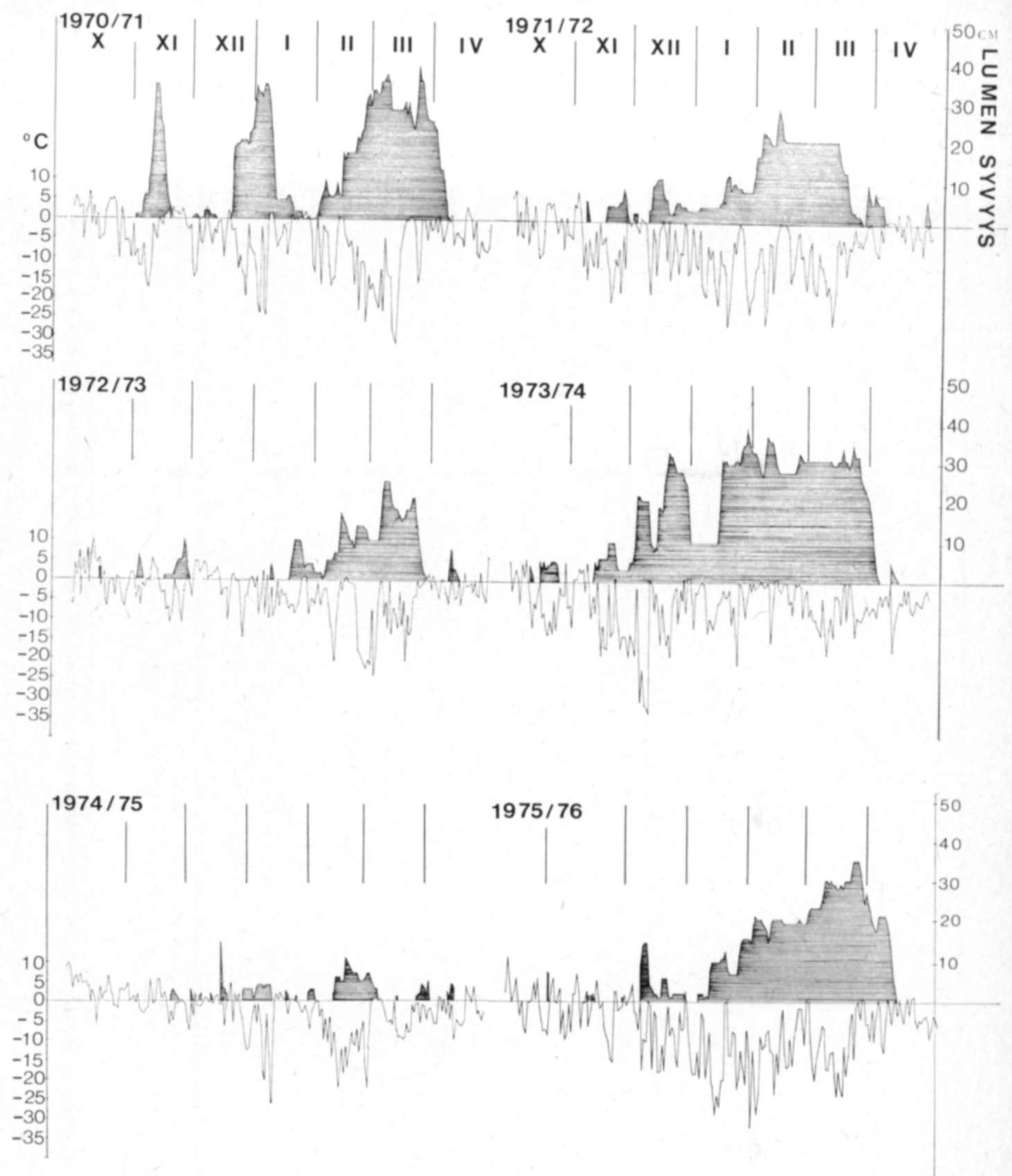

Kuva 2 b. Lumen syvyys - - t talvikausina 1970/71-1975/76.

Fig. 2 b. Depth of snow - - winter 1970/71-1975/76.

sateiden ja lämpimän sään seurauksena. Sateet viivästyttivät ja vaikeuttivat syysviljojen kylvöä, minkä seurauksena kylvöalat supistuivat.

T a lve n $1972 / 73$ kuukausista vain lokakuu oli hiukan normaalia kylmempi, muut kuukaudet olivat sen sijaan keskimääräistä lämpöisempiä. Pysyvä lumipeite saatiin vasta tammikuun 20. päivänä. Se jäi ohueksi ja säilyi maassa vain pari kuukautta. 


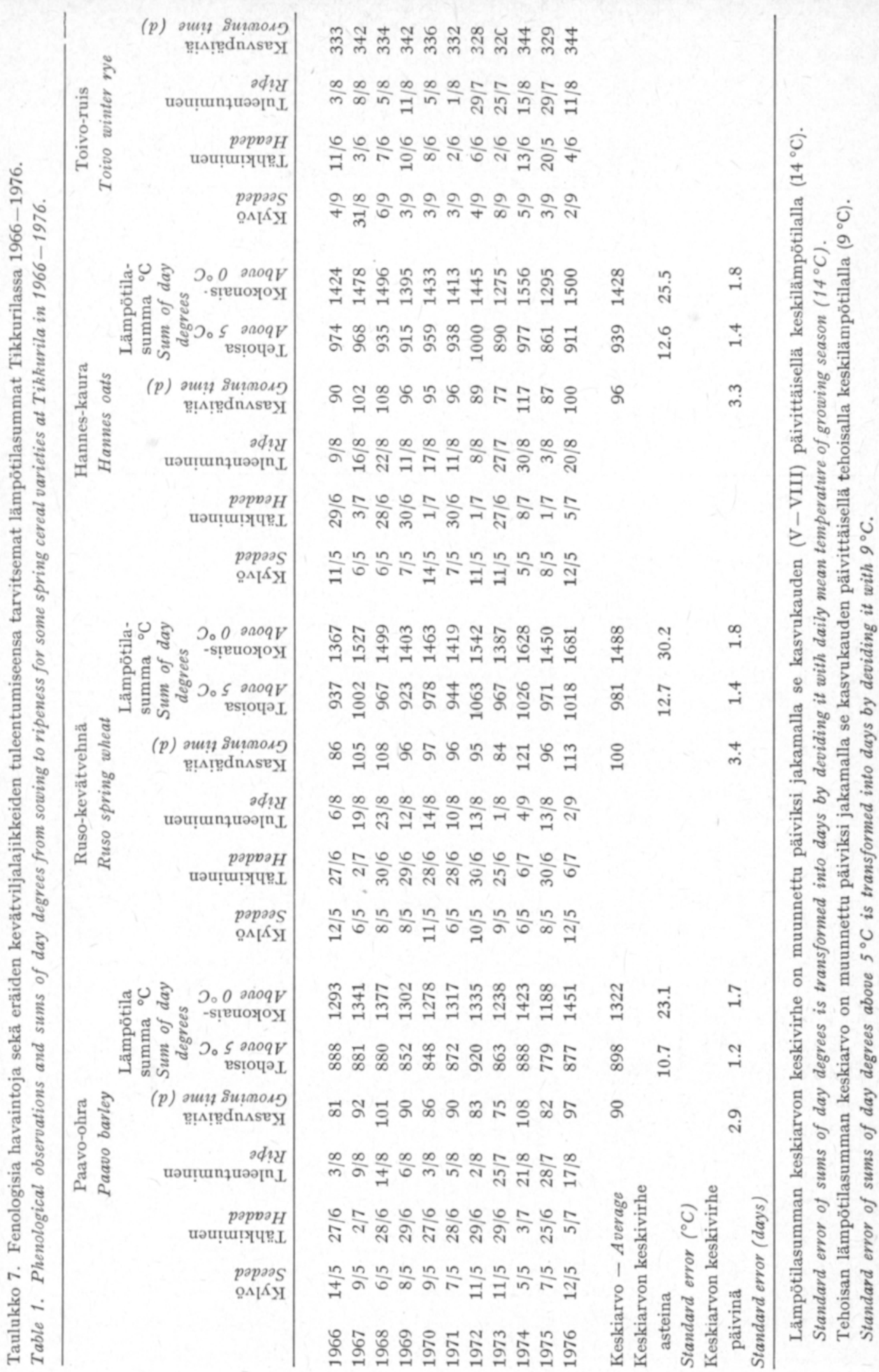


Taulukko 8. Syysviljojen talvituhot (asteikko 0-100) Tikkurilassa 1966-1976.

Table 8. Winter damages (scale 0-100) of rye and wheat at Tikkurila in 1966-1976.

\begin{tabular}{|c|c|c|}
\hline \multirow[b]{2}{*}{$\begin{array}{c}\text { Talvikausi } \\
\text { Winter }\end{array}$} & \multicolumn{2}{|c|}{ Talvituho- $\%$ - Winter damage- $\%$} \\
\hline & $\begin{array}{c}\text { Toivo-ruis } \\
\text { Toivo-rye }\end{array}$ & $\begin{array}{l}\text { Vakka-vehnä } \\
\text { Vakka-wheat }\end{array}$ \\
\hline $1965 / 66$ & 5 & 94 \\
\hline $1966 / 67$ & 2 & 7 \\
\hline $1967 / 68$ & 5 & 28 \\
\hline $1968 / 69$ & 0 & 3 \\
\hline $1969 / 70$ & 0 & 0 \\
\hline $1970 / 71$ & 4 & 6 \\
\hline $1971 / 72$ & 5 & 11 \\
\hline $1972 / 73$ & 1 & 2 \\
\hline $1973 / 74$ & 2 & 18 \\
\hline $1974 / 75$ & 0 & 0 \\
\hline $1975 / 76$ & 0 & 20 \\
\hline
\end{tabular}

Kasvukausi 1973 alkoi lämpöoloiltaan lähes normaalisti. Kesäja heinäkuun keskilämpötilat olivat hyvin korkeat sen sijaan elokuun keskilämpötila oli likimain pitkäaikaista keskiarvoa vastaava. Syyskuulla ilmat muuttuivat normaalia viileämmiksi. Sadeoloiltaan kasvukausi oli Etelä- ja Kaakkois-Suomessa poikkeuksellisen kuiva. Toukokuun sademäärä oli normaali, mutta kesä-, heinä- ja elokuun sademäärät olivat vain kolmanneksen normaalista. Viljat tuleentuivat $2-3$ viikkoa normaalia aikaisemmin. Korkeiden lämpötilojen lisäksi tuleentumista nopeutti ankara kuivuus. Viljasadon kunto oli hyvistä korjuuoloista johtuen hyvä, mutta satotaso oli alhainen. Heinäsadot ja ensimmäinen säilörehusato muodostuivat kevätkosteuden turvin hyviksi, mutta myöhemmin niitto- ja laidunnurmen kasvu pysähtyi kokonaan. Perunasadot jäivät heikoiksi kuivuuden ja syyshallojen vuoksi. Syyskuu oli Tikkurilassa runsassateinen, mikä vaikeutti syysviljojen kylvöä.

Talvikauden $1973 / 74$ syyspuolen säät olivat normaalia paljon kylmemmät, mikä hidasti oraiden kehitystä. Vuoden 1974 alkukuukaudet olivat leudot ja talvi melko vähäluminen. Lumet sulivat maaliskuun alkuun mennessä, jonka jälkeen kylmät säät ja kovat tuulet heikensivät talvehtineita oraita.

Kas vukauden 1974 kesäkuukaudet olivat viileämpiä verrattuna pitkäaikaisiin keskilämpötiloihin. Kesä oli heinäkuusta lähtien runsassateinen. Tosin Tikkurilassa mitatut heinä- ja elokuun sademäärät eivät olleet normaaleja runsaammat, mutta sadepäiviä oli sen sijaan lukuisasti. Koko loppuvuosi jatkui sateisena, niin että vuoden sademäärä Tikkurilassa oli $286 \mathrm{~mm}$ yli normaalin. Kuivan alkukesän seurauksena päästiin kylvöt aloittamaan normaalia varhaisemmin. Kylvöjen jälkeen kasvukauden säät olivat kasvien kasvulle edulliset. Kevätkylvöisten kasvien kehitys oli rehevää, syyskylvöisten kasvu jäi lähinnä vaikean alkukevään vuoksi heikommaksi. Viileän kesän vuoksi tuleentuminen tapahtui $10-14$ vrk normaalia myöhemmin. Kasvustojen runsas lakoutuminen niinikään hidasti tuleentumista. Kasvukauden runsaat sateet heikensivät sekä heinän että viljojen laatua. Syksyllä sattuneet sateet 
vaikeuttivat syyskylvöjen suorittamista. Seurauksena oli, että rukiin ja syysrypsin kylvöalat supistuivat lähes puoleen ja syysvehnän noin neljäsosaan edelliseen vuoteen verrattuna.

T a lvi $1974 / 75$ oli lähes lumeton, runsaimmin $(6-10) \mathrm{cm}$ oli lunta helmi-maaliskuun vaihteessa vajaan kuukauden ajan.

K a svukausi 1975 alkoi erittäin lämpimänä, toukokuun lämpötila oli yli $2^{\circ} \mathrm{C}$ normaalia korkeampi. Toukokuun lopulla ja kesäkuun alussa oli kuitenkin erittäin viileä kausi, jolloin esiintyi ankaria yöpakkasia. Kesäkuu jäi Tikkurilassa keskimäärin normaalia viileämmäksi, mutta heinä-, elo- ja syyskuu olivat pitkäaikaisiin keskiarvoihin verrattuna $1 \ldots 2.5^{\circ} \mathrm{C}$ lämpimämmät. Koko kesä ja syksy olivat erittäin vähäsateiset. Lämpimän varhaiskevään vuoksi syysviljojen kehitys oli nopeata, niinpä esim. Toivo-ruis tuli tähkälle ennätyksellisen varhain 20/5. Touko-kesäkuun vaihteen yöpakkasten aikana ruis oli juuri tullut tähkälle ja syysvehnäkin oli lähellä tähkimistä. Tästä huolimatta niiden satotaso Tikkurilassa muodostui erittäin korkeaksi. Silti Etelä-Suomessa arvioitiin rukiin satotason alentuneen yleisesti hallojen vuoksi. Kevätkylvölle päästiin heti toukokuun alussa. Kevään yöpakkasista oraat toipuivat hyvin, mutta kuivuuden vuoksi kasvustot Etelä-Suomessa jäivät paikoin erittäin heikoiksi ja satotaso vaatimattomaksi. Alueelliset erot olivat suuret. Tuleentuminen oli nopeata, monin paikoin kuivuus ja korkea lämpötila tuleennuttivat viljat ennen aikaisesti. Sama koski nurmikasveja. Heinänkorjuu alkoi varhain ja sato oli laadultaan hyvää, mutta myöhemmin kuivuus tyrehdytti nurmien jälkikasvun kokonaan. Syyskylvöt suoritettiin edullisten sääolojen vallitessa ja kylvökset taimistuivat hyvin.

T a lvikausi $1975 / 76$. Syksy 1975 oli keskimääräistä lämpimämpi ja vähäsateisempi. Pysyvä lumi tuli maahan vasta tammikuun alussa. Lumipeite oli ohut, vahvimmillaan $(37 \mathrm{~cm})$ se oli maaliskuun puolessa välissä. Routa ulottuikin lopputalvella erittäin syvälle, yli $80 \mathrm{~cm}: n$ ja suli vasta toukokuun alkupäivinä. Ruis talvehti Tikkurilassa hyvin, mutta syysvehnä kärsi kevään tuulisista ja erittäin kuivista säistä. Nurmikasvit talvehtivat hyvin.

Kasvukausi 1976. Roudan myöhäisestä sulamisesta huolimatta aloitettiin kevätkylvöt Tikkurilassa lähes normaalina ajankohtana 10/5. Toukokuu oli keskimäärin normaalia lämpimämpi, mutta muut kasvukauden kuukaudet olivat erittäin viileät, keskimäärin oli touko - elokuun lämpötila $-0.4^{\circ} \mathrm{C}$ pitkäaikaista keskiarvoa alhaisempi. Sademäärät jäivät Tikkurilassa jonkin verran alle pitkäaikaisten keskiarvojen, mutta alkukesän sademäärät olivat lähellä normaaliarvoja. Tarkastelun kohteena olevista vuosista ainoastaan kahden, vuosien 1972 ja 1974, kesäkuun sademäärät olivat suuremmat kuin kesän 1976. Kun lisäksi säät olivat viileät, jäi haihdunta pieneksi. Kasvit eivät missään vaiheessa kärsineet veden puutteesta, jonka vuoksi sadot muodostuivat määrältään runsaiksi. Viileästä säästä johtuen tuleentuminen edistyi kuitenkin hitaasti ja viljojen valmistuminen ja puinti viivästyivät huomattavasti normaalista. Elokuun lopulla esiintyneet lievät syyshallat eivät etelärannikolla aiheuttaneet pahoja vahinkoja kasvustoille. Sen sijaan monin paikoin muualla Suomessa heikkeni myöhäisten kevätviljojen sadon laatu ankarien syyshallojen vuoksi. Korjuutöiden viivästymisen takia syysviljojen kylvöajat pienenivät edelliseen vuoteen verrattuna. 


\section{Sääolojen tarkastelua}

Useimmat tarkastelun kohteena olevat kasvukaudet olivat lämpimämmät kuin kolmikymmenvuotiskauden 1931-1960 kasvukaudet keskimäärin, viileämpiä olivat ainoastaan vuodet 1968, 1974 ja 1976. Kasvukaudet 1972 ja 1973 olivat erittäin lämpimiä, touko-elokuun keskilämpötila oli molempina kesinä $1.6^{\circ} \mathrm{C}$ korkeampi kuin ajankohdan pitkäaikainen keskiarvo. Sadeoloiltaan jakso oli keskimäärin kuiva. Vain kasvukausina 1967 ja 1972 ylitettiin selvästi ajankohdan normaalisademäärät. Kevät 1968 ja 1974 olivat sademääriltään lähellä pitkäaikaisia keskiarvoja, tosin kesällä 1974 sadepäiviä esiintyi lukuisasti. Kaikkina muina kasvukausina sademäärät jäivät ajankohdan pitkäaikaisia keskiarvoja niukemmiksi. Vuosina 1973 ja 1975 sadot jäivät Tikkurilassa kuivuuden vuoksi erityisen heikoiksi. Näinä vuosina kesät olivat myöз hyvin lämpimiä, joten haihduntakin oli erittäin suuri, vain kesällä 1971 se oli vieläkin suurempi. Myös vuonna 1971 poudan vaikutus näkyi selvästi muutamilla kasvilajeilla Tikkurilan kokeissa. Tutkimustoiminnassa ei poutavuosia voida pitää yksinomaan haitallisina, koska ne antavat arvokasta lisätietoutta selvitettäessä eri kasvilajien ja lajikkeiden kuivuudenkestävyyseroja. Sen sijaan käytännön viljelijät ovat tarkastelun kohteena olevana ajanjaksona kärsineet eräinä kasvukausina varsin ankaria kuivuuden aiheuttamia satotappioita. Kuitenkin useista hyvinkin niukkasateisista alkukesistä on selvitty odotettua pienemmin sadonmenetyksin ja satotaso on jatkuvasti kohonnut. Sadon saantia varmentavana tekijänä on ensisijaisesti mainittava aikaisempaa runsaampi lannoitteiden käyttö yhdistyneenä sijoituslannoitukseen. Myös lisääntynyt kasvustojen sadettaminen 1970-luvulla on osaltaan tehokkaasti vähentänyt poutakausien vaikutusta.

Vuosien 1966-76 korjuukausista useimmat olivat Etelä-Suomessa sääoloiltaan edullisia, joten sadon laatu muodostui usein moitteettomaksi. Vaikeimmat korjuuolot vallitsivat vuonna 1974, jolloin merkittäviä satotappioita koettiin erityisesti maan länsirannikolla. Satovahingot muodostuivat tällöin joko kokonaan korjaamatta jääneistä kasvustoista tai korjatun sadon määrällisistä tai laadullisista tappioista.

Kasvukauden aikana sattuneiden hallojen aiheuttamat vahingot jäävät Tikkurilassa yleensä vähäisiksi. Kuitenkin joskus saattaa Etelä-Suomessakin esiintyä kesä-heinäkuulla niin ankaria halloja, että niistä on haittaa erityisesti varhaisperunan viljelylle. Kevätkesä 1975 oli tarkasteltavan jakson hallaisin. Silloin myös syysviljoissa todettiin Etelä-Suomessa yleisesti sadon määrään vaikuttavia hallavaurioita. Aikaiset syyshallat saattavat myös aiheuttaa vahinkoja sekä perunalle että tuleentumattomille viljoille etelässäkin. Vuosina 1966-1976 ei Tikkurilassa eikä yleensäkään etelä-rannikolla sattunut syksyisin pahoja hallavahinkoja. Kasvukaudet olivat sikäli edullisia, että useimmat viljalajikkeet olivat täysin tuleentuneet ensimmäisten syyshallojen sattuessa.

Sääolojen vaikutusta kasvien kehitykseen voidaan tarkastella taulukon 7 avulla. Viljojen tuleentumisen ajankohta vaihteli lähes kuukauden riippuen kasvukauden säistä ja kylvöajasta. Kasvupäivien luku samalla lajikkeella oli mÿös erittäin vaihteleva eri vuosina. Niinpä Paavo-ohralla suurin ero kas- 
vuajoissa oli 33 päivää, Hannes-kauralla 40 päivää ja Ruso-kevätvehnällä 37 päivää. Kasvuaikaa on myös mitattu tuleentumiseen tarvittavalla kokonaislämpötilasummalla sekä tehoisalla lämpötilasummalla (SALMINEN 1930, Sinisalo 1937, Nuttonson 1957, PaAtela ja Suomela 1962, Kivi ja Rekunen 1976). Taulukon alaosassa esitetään eri tavoin ilmaistujen kasvuaikojen keskiarvot ja niiden hajontaa kuvaavat keskiarvon keskivirheet. Lämpötilasummien keskivirheet on muutettu takaisin päiviksi jakamalla astemäärä kasvukauden (touko-elokuun) päivittäisellä keskilämpötilalla tai päivittäisellä tehoisalla keskilämpötilalla. Tuleentumiseen tarvittava tehoisien lämpötilojen summa osoittautui tarkasteltavina vuosina tarkimmaksi kasvuajan mitaksi. Sen avulla mitatun kasvuajan hajonta jäi jokaisella viljalla hieman pienemmäksi kuin kokonaislämpötilasummalla mitatun kasvuajan hajonta. Molempia lämpötilasummia käytettäessä jäi kasvuaikojen vaihtelu huomattavasti pienemmäksi kuin päivinä ilmaistun kasvuajan vaihtelu.

Tehoisalla lämpösummalla mitattujen kasvuaikojen pituuksien suurin ero oli Paavo-ohralla $141^{\circ} \mathrm{C}=16 \mathrm{pv}$, Ruso-kevätvehnällä $140^{\circ} \mathrm{C}=16 \mathrm{pv}$ ja Hannes-kauralla $139^{\circ} \mathrm{C}=15 \mathrm{pv}$.

Kasvuajan pituuteen vaikuttaa siis ratkaisevasti lämpötila, mutta myös sateiden vaikutus on selvästi havaittavissa. Erityisen kuivina vuosina kasvuaika jäi lyhyeksi ja lämpötilasumma pieneksi ilmeisesti siksi, että kasvu pysähtyi ennenaikaisesti veden puutteen vuoksi. Erittäin suureksi kasvoi tuleentumiseen tarvittava lämpötilasumma Tikkurilassa paitsi hyvin lämpimänä kasvukautena 1972, jolloin vettä oli riittävästi, myös erittäin viileinä kasvukausina 1974 ja 1976. MukULA ym. (1977) ovat todenneet ohran tuleentumiseensa tarvitseman lämpötilasummavaatimuksen suurenevan lämpiminä kasvukausina, kun taas viileinä kasvukausina ohralajikkeiden lämpötilasummavaatimukset jäivät keskimäärin pieniksi. Tässä tarkastelussa esitetyt havainnot viileiltä kasvukausilta poikkeavat siis MukULAn ym. tutkimuksista. Tämä saattaa johtua siitä, että kasvukaudet 1974 ja 1976 olivat useita vertailtavia vuosia sateisempia. Kuivuus ei siis muodostunut kasvua rajoittavaksi tekijäksi, kuten tutkimusjakson kuivempina vuosina Tikkurilassa. Sen vuoksi viljojen tuleentumiseensa tarvitsemat lämpötilasummatkin todennäköisesti kasvoivat kuivempien kasvukausien lämpötilasummavaatimuksia suuremmiksi.

Lämpimänä kesänä kasvien tuleentumiseen tarvitsema korkea lämpötilasumma viittaa siihen, että viljelykasvimme eivät pysty täysin käyttämään hyväkseen meillä epätavallisen korkeita päivälämpötiloja. Viileänä kasvukautena taas auringonpaistetuntien vähäisyys osaltaan hidastaa varsinkin kasvien tuleentumista (VALmari 1972). Kasvien kasvulla saattaa eri kehitysvaiheissa siten olla optimilämpötila-alueensa ja muissa lämpötiloissa niiden kasvu ja kehitys hidastuu. Edellä esitetyillä tavoilla lasketuilla lämpötilasummilla ei näin ollen olisi mahdollista täysin tarkoin kuvata kasvuajan pituutta. Kuitenkin niiden avulla kasvuaikaa voitaneen mitata tarkemmin kuin ilmoittamalla kasvupäivien lukumäärä.

Tarkastelun kohteena olevalla kaudella olivat talvehtivien kasvien kannalta vaikeimpia Etelä-Suomessa talvet 1965/66, 1967/68 sekä 1973/74 (taulukko 8). Ensin mainittuna vuotena heikkoon talvehtimiseen olivat syynä talvituhosienien aiheuttamat vauriot. Talvikautena 1967/68 kasvit kärsivät 
lähinnä lumen sulamisen jälkeen sattuneista pakkasista. Talvella runsas lumipeite suojasi talvehtivia kasvustoja melko tehokkaasti. Kevättalven kylmät ja tuuliset säät olivat niinikään talvikautena 1973/74 pääasiallinen syy kasvustojen talvituhoihin Etelä-Suomessa. Vuonna 1976 syysvehnät talvehtivat Tikkurilassa huomattavasti huonommin kuin yleensä etelä-rannikolla. Syynä olivat kevään ankarat olosuhteet ja koelohkojen epäedullinen sijainti.

\section{Tiivistelmä}

Tutkimusjakson kasvukaudet olivat vuosina 1968, 1974 ja 1976 lukuunottamatta lämpimämpiä kuin pitkän ajanjakson (1930-1960) kasvukaudet keskimäärin. Erityisen lämpimiä olivat kesät 1972 ja 1973. Tarkastelun kohteena olevat kasvukaudet olivat keskimäärin kuivia, vain kesinä 1967 ja 1972 ajankohdan normaalisademäärät ylitettiin selvästi. Kasvukauden sateet ajoittuvat kuitenkin usein epäedullisesti sikäli että alkukesä on kuiva, mutta korjuukausi sateinen. Korjuukauden runsaiden sateiden aiheuttamista puintivaikeuksista ja sadon laadun heikentymisestä johtuvia satotappioita koettiin tutkimusjakson aikana Etelä-Suomessa erityisesti vuosina 1972 ja 1974 .

Kasvukauden aikana sattuneiden hallojen aiheuttamat vahingot jäävät maamme etelärannikolla yleensä vähäisiksi. Vuonna 1975 esiintyi kuitenkin harvinaisen ankaria keväthalloja syysrukiin tähkälletulovaiheessa ja ne aiheuttivat paikoin satovahinkoja. Jakson aikaisimmat syyshallat koettiin vuosina 1966 ja 1976. Nekin sattuivat kuitenkin vasta elokuun lopulla ja syyskuun alussa eivätkä siten Tikkurilan oloissa enää aiheuttaneet satovahinkoja peltokasveille. Talvehtivien kasvien kannalta vaikein oli runsasluminen talvikausi 1965/66, jolloin talvituhosienien aiheuttamat tuhot olivat yleisiä.

Tutkimuksessa todettiin myös, että kylvöstä tuleentumiseen laskettu lämpötilasumma on kevätviljojen osalta tarkempi kasvuajan mitta kuin yleisesti käytössä oleva kasvupäivien lukumäärä.

\section{KIRJALLISUUSLUETTELO}

Krvi, E \& ReKunen, M. 1976. Ohra. Hankkijan kasvinjalostuslaitos Siemenjulkaisu.

Mukula, J., Rantanen, O. \& Lallukka, U. 1977. Ohran viljelyvarmuus Suomessa 19501976. Maatalouden tutkimuskeskus, Kasvinviljelylaitoksen Tiedote N:o 9.

Nutronson, M. Y. 1957. Barley-climate relationship and the use of phenology in ascertaining the thermal and photothermal requirements of barley. Washington $280 \mathrm{p}$.

PaAtela, J. \& Suomela, H. 1962. Peltokasvien sadoista, niiden määrään vaikuttavista tekijöistä ja odotettavissa olevasta kehityksestä. Helsinki 1962, 38 s.

SALmrNen, M. 1930. Kasvuajan, sademäärän ja keskilämpötilan vaikutus lämpöasteiden summaan ja kasvuajan pituuteen Tammistossa 1925-29. Hankkijan kasvinjalostuslaitos, Siemenjulkaisu 1930: 7-92.

Sinisalo, J. 1937. Die für das Reifen gewisser Sommerweizen und Gerstensorten erforlichen Wärmesummen und Anzahlen von Wachstumstagen. J. Scient. Agric. Soc. Finl. 9: $194-212$. 
VALLE, O. 1958. Sääolot ja niiden vaikutus kasvintuotantoon Etelä-Suomessa 1946-57. Maatal. ja Koetoim. 12: 18-36.

— - 1962. Sääolot ja niiden vaikutus kasvintuotantoon Etelä-Suomessa 1958-61. Maatal. ja Koetoim. 16: 38-50.

— - 1966. Sääolot ja niiden vaikutus kasvintuotantoon Etelä-Suomessa 1962-65. Maatal. ja Koetoim. 20: 29-39.

VALMARI, A. 1972. Säätekijäin vaikutus ohran ja kauran kehitysnopeuteen. Liite N:o 2 Hallakoeaseman toimintakertomukseen vuodelta 1972.

Käsikirjoitus saapunut 4.1.1978 